This item was submitted to Loughborough's Research Repository by the author.

Items in Figshare are protected by copyright, with all rights reserved, unless otherwise indicated.

\title{
Binding mechanisms of radionuclides to cement
}

PLEASE CITE THE PUBLISHED VERSION

PUBLISHER

(C) Elsevier

LICENCE

CC BY-NC-ND 4.0

REPOSITORY RECORD

Evans, Nicholas D.M.. 2019. "Binding Mechanisms of Radionuclides to Cement". figshare. https://hdl.handle.net/2134/3262. 
This item was submitted to Loughborough's Institutional Repository by the author and is made available under the following Creative Commons Licence conditions.

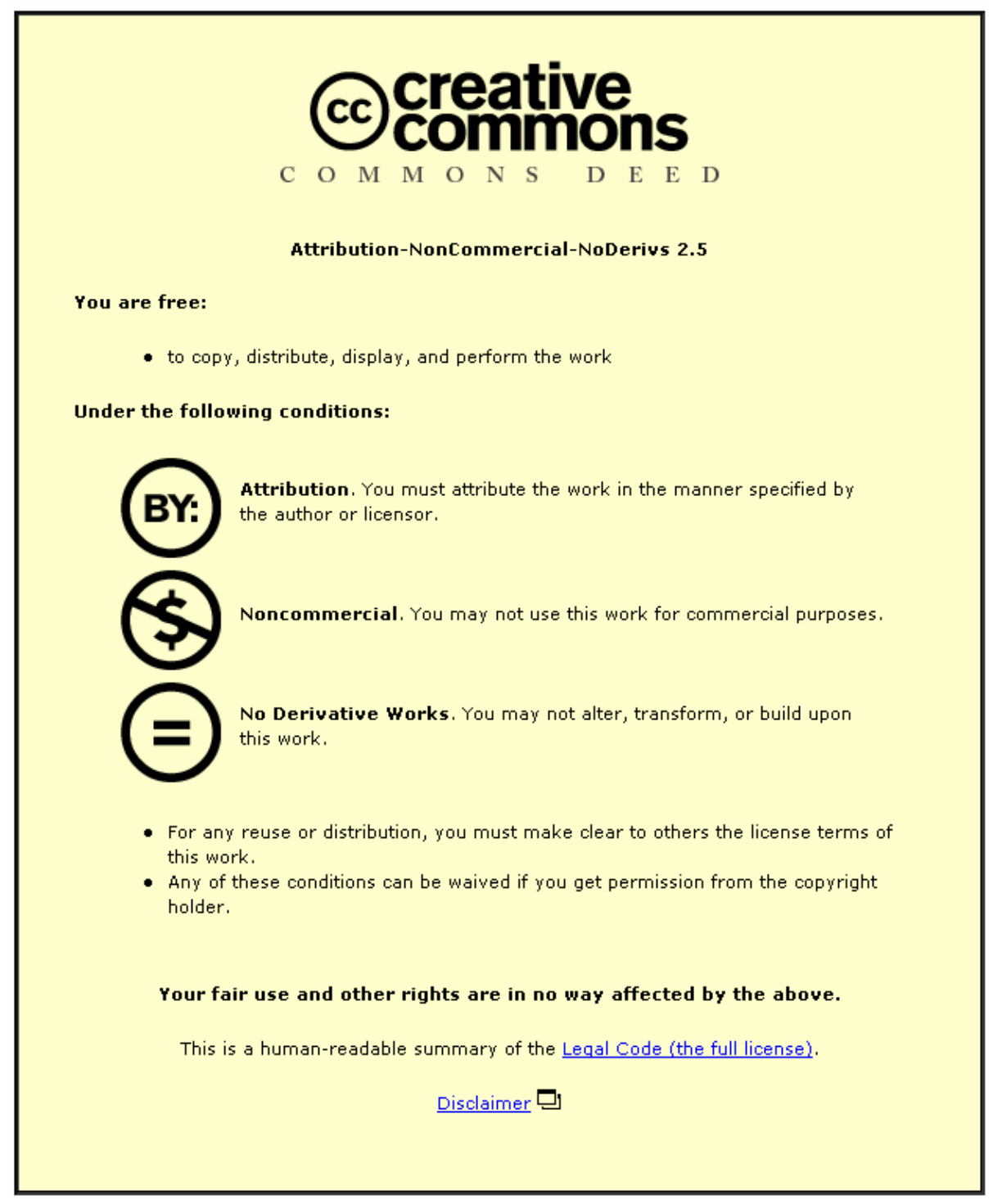

For the full text of this licence, please go to: http://creativecommons.org/licenses/by-nc-nd/2.5/ 


\title{
Binding mechanisms of radionuclides to cement
}

\author{
N.D.M. Evans* \\ Department of Chemistry, Loughborough University, Loughborough, \\ Leics, LE11 3TU, UK
}

*Author for correspondence: n.d.m.evans@1boro.ac.uk 


\begin{abstract}
Radionuclide solubility is one of the factors that can determine the 'source term' for potential migration to the far field. Hence, the mechanisms of immobilisation of radionuclides in cements need close study in order to quantify the nature of the binding. The nature of the binding forces in a cement matrix is very species sensitive, so it is difficult to produce a general description. This review summarises the main sorption mechanisms and then details immobilisation mechanisms for many elements.
\end{abstract}




\section{Introduction}

Radionuclide solubility is one of the factors, along with sorption and inventory, that can determine the 'source term' for potential migration to the far field of a nuclear waste repository. Several processes can affect the concentration of a radionuclide in cement porewater, e.g.:

a) precipitation as a simple salt;

b) coprecipitation with other phases;

c) lattice incorporation in the major cement hydration products (solid solution);

d) sorption at hydrous surfaces (chemisorption, adsorption);

e) complex and colloid formation in the aqueous phase [1].

The best case for retardation of radionuclide mobility is to have a low aqueous solubility, with a robust solubility controlling phase. An understanding of interaction mechanisms is important where data are required for performance assessment that are outside the range of experimental systems studied (e.g. $\mathrm{pH}$ range, timescales). If the wrong mechanism is assumed, this could lead to inappropriate values being selected on estimation. It should be noted that mechanisms found to occur on laboratory timescales are not necessarily those that will operate on much longer (repositoryrelated) timescales.

One aspect that is not covered in this review is the effect of carbonation of cements on radionuclide immobilisation. This is due to insufficient data being available in the literature used to compile this review.

Sorption is a generic term, which covers the processes of absorption, physical adsorption and chemical adsorption. Sorption mechanisms depend on the chemical speciation of the sorbate, and the chemical and physical properties of the sorbent. 
Absorption is the incorporation of a sorbate within the physical or molecular structure of a sorbent, i.e. the sorbate has access to the bulk, not just the surface, of the sorbent. Physical adsorption can be divided into three types:

(a) Surface complexation, which is mixture of chemical and electrostatic interactions;

(b) Ion exchange, which is an example of electrostatic adsorption due to coulombic forces of attraction between charged sorbate species and the sorbent;

(c) Other mechanisms, e.g. solid-solution formation, co-precipitation.

The most important reactions of cement with waste are those which lead to binding [2], i.e. a chemical reaction. The nature of the binding forces in a cement matrix is species specific, so it is difficult to produce a general description. Many species also form one or more solubility-limiting phases by reaction with cement components. "Solubility-limiting" implies the formation of a phase which would not ordinarily exist in cement, because it contains one or more radioactive species.

\section{Review of Reported Immobilisation Mechanisms by Element}

\subsection{Group I Elements}

The sorption of $\mathrm{Li}, \mathrm{Na}, \mathrm{K}$ and $\mathrm{Cs}$ on calcium silicate hydrate (CSH) studied by Iwaida et al. [3], was found to increase inversely in proportion to the Stokes radius of the hydrated ions for cements with various $\mathrm{Ca}: \mathrm{Si}$ ratios. The authors concluded that sorption was electrostatic on a negatively charged CSH site. Hong et al. have suggested [4] that this is at silanol $(\mathrm{Si}-\mathrm{OH})$ sites, arising from the density of silanol bonds and the sites' mean acidity, both of which increased as the Ca:Si ratio decreased [4]. 


\subsubsection{Caesium}

The binding capacity of cement for Cs is dependent on chemical composition, as the different phases have different binding capacities [5]. Cs retention has been found to increase with increasing $\mathrm{CaO}: \mathrm{Al}_{2} \mathrm{O}_{3}$ ratio, yet $\mathrm{R}_{\mathrm{d}}$ values remain almost constant if the quantity of $\mathrm{SiO}_{2}$ in the matrix composition increases in the same ratio [5]. However, Cs retention was found to decrease with increasing $\mathrm{SiO}_{2}: \mathrm{CaO}$ ratio [5], the opposite effect was found by Noshita and Aggarwal et al. [6], but not commented upon by the authors. Sorption decreased further with increasing alumina content, at constant $\mathrm{SiO}_{2}: \mathrm{CaO}$ ratio. Similarly, for compositions with constant $\mathrm{Al}_{2} \mathrm{O}_{3}: \mathrm{SiO}_{2}$ content, an increase in the Ca:Si ratio resulted in a decrease in $\mathrm{R}_{d}$ values, although increasing the $\mathrm{CaO}$ content with a constant $\mathrm{Al}_{2} \mathrm{O}_{3}: \mathrm{SiO}_{2}$ ratio increased Cs retention [5].

Solid-state NMR was used to investigate Cs speciation in cements by Hanna et al. [7]. Cs in Ordinary Portland Cement (OPC) appeared to remain in solution, whether or not blast furnace slag (BFS) or Condensed Silica Fume (CSF) were present. Differences due to Cs partly inhabiting semi-crystalline or amorphous solid sites were observed after 1 year in the slag-containing cement, but the majority of the Cs was apparently restricted to partially or fully solvated states in the aqueous phase. However, Atkinson et al. [8] concluded that the diffusivity of $\mathrm{Cs}^{+}$ions in OPC was significantly lower than that of $\mathrm{Cl}^{-}$and $\mathrm{Na}^{+}$ions. The use of zeolite as a blending material in cement has been found to cause an 80-fold reduction in Cs leaching [9] [10], and in other studies, the use of slag also had an influence by a factor of 4-5 on leaching [11] [12].

Sorption experiments with ${ }^{137} \mathrm{Cs}$ on four types of concrete (normal density, normal density with fuel ash, high density and high density with silica fume) were carried out by Jakubick et al. [13] in 3 groundwaters. Cs showed no significant sorption on normal-density concrete and sorption on carbonate aggregates was also very low. Greater sorption occurred along the cleavage planes of gneiss aggregates containing mafic minerals (biotite and pyroxene). The high-density sample showed preferential sorption of $\mathrm{Cs}$ on the magnetite aggregates and on the fine grains of specularite, a 
variety of haematite characterised by aggregates of silvery, metallic, specular haematite flakes or tabular, anhedral crystals, also known as grey haematite.

The identification of the hydrated phases responsible for Cs incorporation in concrete was investigated by Hoyle et al. [14]. Calcium aluminosilicate glasses were mixed with $\mathrm{CsOH}$ or $\mathrm{CsCl}$ solutions and allowed to hydrate. Glasses exposed to $\mathrm{CsOH}(\mathrm{aq})$ were more reactive than their counterparts exposed to $\mathrm{CsCl}(\mathrm{aq})$. At least two Cscontaining zeolites were identified in the $90^{\circ} \mathrm{C} \mathrm{CsOH}$ solution; a Cs-containing wairakite $\left(\mathrm{CaAl}_{2} \mathrm{Si}_{4} \mathrm{O}_{12} \cdot 2 \mathrm{H}_{2} \mathrm{O}\right)$ analogue, and another unidentified Cs-containing zeolite. However, strätlingite did not appear to take up Cs.

Noshita et al. [15] found that Cs was highly sorbed by calcium silicate compounds (in agreement with [6]). It was sorbed onto those with lower Ca:Si molar ratios, such as $\mathrm{CSH}$. This suggests that sorption was mainly determined by Ca:Si ratios, regardless of crystal structure. Iwaida et al. [3] observed a shortening of the silicate chains in $\mathrm{CSH}$ which had sorbed Cs, indicating breakage of the silicate chains had occurred. The authors suggested that hydroxide played an important role in this process. Energy dispersive analysis of silica fume clusters in cement by Bar-Nes et al. [16] suggested that Cs tends to concentrate inside agglomerated silica particles.

\subsubsection{Sodium}

Sodium substitutions in CSH phases have been reported [17]. CSH gel dissolution experiments in $\mathrm{NaCl}(\mathrm{aq})$ showed an increase in $\mathrm{Ca}$ concentration at higher $\mathrm{Na}$ concentrations. This was interpreted in terms of an ion exchange process between $\mathrm{Ca}$ and $\mathrm{Na}$ [18], although an alternative explanation could lie in the formation of chlorocomplexes.

\subsection{Actinides}

\subsubsection{Americium}


Experiments [13] using ${ }^{241} \mathrm{Am}$ have indicated preferential sorption in cementitious paste. Normal-density specimens containing fuel ash sorbed more than standard compositions, with voids showing rims of enhanced sorption. Considerable sorption was observed on carbonate aggregates and mafic components of the granitic and gneiss aggregates. A slightly higher sorption on magnetite than on specularite or hematite was observed [13]. Baston et al. [19] quantified Am sorption data using a surface complexation model, in which the main surface sites were $>\mathrm{SiO}^{-}$and $>\mathrm{SiOCaOH}$, with Am hydroxide species assumed to be the sorbing species. Noshita et al. [20], have found that Am is highly sorbed onto CSH gel, and they concluded that Am is anionic in cement.

\subsubsection{Curium}

Stumpf et al. using time-resolved laser fluorescence spectroscopy (TRLFS) [21] identified 4 different $\mathrm{Cm}$ (III) species. A non-fluorescing species which corresponds to curium hydroxide real colloids, a fluorescing $\mathrm{Cm}$ (III)-portlandite sorption species, and two fluorescing Cm(III)-CSH species. From fluorescence emission lifetimes it was predicted that the two fluorescing $\mathrm{Cm}(\mathrm{III})-\mathrm{CSH}$ species had 1 to 2 , and zero water molecules respectively, in their $1^{\text {st }}$ coordination sphere, suggesting that these species were incorporated in the CSH structure. Measurements on HCP systems in artificial cement pore-water showed that initially $\mathrm{Cm}$ (III) is sorbed on the portlandite fraction. With time, two forms of $\mathrm{Cm}$ (III) incorporated in the $\mathrm{CSH}$ fraction, where it occupies 2 different positions in the CSH structure [22], became dominant.

\subsubsection{Neptunium}

Sylwester et al. [23] observed a reduction from $\mathrm{Np}(\mathrm{V})$ to $\mathrm{Np}(\mathrm{IV})$ as it interacted with $\mathrm{OPC}$; the amount of reduction increasing with equilibration time. The absence of $\mathrm{Np}$ $\mathrm{Np}$ interactions in the extended X-ray absorption fine structure (EXAFS) spectra provided evidence that $\mathrm{Np}$ partitioning was controlled by sorption of $\mathrm{Np}(\mathrm{V})$, followed by reduction, and not by reduction followed by formation of $\mathrm{Np}$ (IV) surface precipitates. Matzen et al. [24] identified immobilised $\mathrm{Np}$ at, or near, the fracture surface when soluble and colloid-associated $\mathrm{Np}$ were eluted into a fractured, hydrothermally altered, concrete core. 


\subsubsection{Plutonium}

Jakubick et al. [13] have shown that the surface distribution pattern of $\mathrm{Pu}$ follows the concrete structure selectively. Preferential sorption in the cement paste over that on aggregates was characteristic of both normal and high-density concrete. Sorption on carbonate aggregates was slightly higher than, or comparable with, that on gneiss fragments. Sorption patches of $\mathrm{Pu}$ were also observed on the mafic components of the granitic aggregates. However, the quartz components remained inactive. In the high-density concrete, the magnetite aggregates proved to be more sorptive than hematite and specularite. Aggarwal et al. [6] found that sorption increased with increasing fraction of OPC in PFA/OPC blends. There was a downward trend in $\mathrm{R}_{d}$ with decreasing $\mathrm{Ca}$ :Si ratio for $\mathrm{C}_{3} \mathrm{~S}$ hydrates. Comparison of the sorption on cements with that on $\mathrm{CSH}$, indicated that most sorption occurred on the $\mathrm{CSH}$, but in $\mathrm{BFS} / \mathrm{OPC}$ blends, other phases may have contributed.

\subsubsection{Thorium}

Tits et al. [25] have shown that the sorption process controlling the retention of Th(IV) on CSH is fast. Sorption distribution ratios in the range of $10^{5}$ to $10^{6} \mathrm{dm}^{3} \mathrm{~kg}^{-1}$ were found.

\subsubsection{Uranium}

The reactions between $\mathrm{CaO}, \mathrm{SiO}_{2}$ and schoepite $\left(\mathrm{UO}_{3} .2 \mathrm{H}_{2} \mathrm{O}\right)$ were studied by Moroni et al. [26] in aqueous suspensions at $85^{\circ} \mathrm{C}$. Several solubility-limiting, but hitherto uncharacterised, $\mathrm{CaO}-\mathrm{UO}_{3}-\mathrm{SiO}_{2}-\mathrm{H}_{2} \mathrm{O}$ phases were described. It was concluded that weeksite-like and becquerelite-like structures were probably developed. With the formation of crystalline phases, $U$ solubilities declined to the region of $10^{-8}-10^{-9} \mathrm{~mol}$ $\mathrm{dm}^{-3}$. Some slight U sorption into the gel may have occurred. Sylwester et al. [23] have shown that $\mathrm{U}$ remains in the form of $\mathrm{UO}_{2}{ }^{2+}$. Evidence of inner-sphere interactions on both treated and untreated cements at all $\mathrm{pH}$ values was found, with $\mathrm{UO}_{2}{ }^{2+}$ complexing with the mineral surface via sharing of equatorial oxygens. On 
hydrothermally treated cement near-neighbour U-U interactions were also observed, indicating the formation of oligomeric surface complexes, or surface precipitates.

Wet chemistry and EXAFS studies on U(VI) uptake by HCP by Wieland et al. [27] showed that sorption was linear up to about $6 \times 10^{-6} \mathrm{~mol} \mathrm{dm}^{-3}$. Above this, the immobilisation was due to the formation of a calcium uranate precipitate. A study by Pointeau et al. [28] showed that the uptake of U(VI) increased when comparing the least and most degraded cement pastes, whereas the initial composition of the cement had relatively little effect. Sorption isotherms were linear with a slope of 1 , indicating the predominance of sorption processes. As sorption and desorption values were close, the uptake mechanism seemed to be reversible.

Harfouche et al. [29] either sorbed U(VI) onto previously precipitated CSH phases (sorption samples) or added during C-S-H synthesis (coprecipitation samples). The coordination environment of U(VI) in the sorption samples was independent of CSH Synthesis procedure. The coordination environment of U(VI) in the coprecipitated samples depended on the synthesis method, and the spectra differed from those for the sorption samples.

\section{3 'P' Block Elements}

\subsubsection{Arsenic}

Kumarathasan et al. [30] observed the replacement of $\mathrm{SO}_{4}{ }^{2-}$ by arsenate in ettringite, and quasi-instantaneous equilibrium ( $<1 \mathrm{~min}$ ) was observed by Myneni et al. [31] for this process. A study by Phenrat et al. [32] found As-Fe hydroxide sludge to be immobilised by 3 mechanisms, sorption onto the $\mathrm{CSH}$ surface, replacing $\mathrm{SO}_{4}{ }^{2-}$ in ettringite and, predominantly, the formation of solubility-limiting $\mathrm{Ca}-\mathrm{As}$ compounds.

Stronach et al. [33] report that hydrated Portland cement limits the solubility of As(III) to $7.0 \mathrm{mmol} \mathrm{kg}{ }^{-1}$. The authors also observed that this is due to the substantial buffering reserve of $\mathrm{Ca}(\mathrm{OH})_{2}$, which is in theory able to immobilise 1 As atom per $\mathrm{Ca}$ atom by the formation of the sparingly soluble $\mathrm{CaAsO}_{2} \mathrm{OH}$. 


\subsubsection{Organic Carbon}

Batch sorption experiments using acetic acid, formaldehyde, acetaldehyde and arginine were carried out by Matsumoto et al. on various types of cementitious mortars [34] at different pHs. The sorption experiments showed that aqueous organic ${ }^{14} \mathrm{C}$ was not sorbed to any great extent on mortar at high $\mathrm{pH}$. In the mortaracetaldehyde system sorption was not affected by $\mathrm{pH}$. In the mortar-arginine system, it was found that sorption behaviour changed on either side of the isoelectric point of arginine, i.e. sorption of negatively charged arginine above $\mathrm{pH} 12.5$ was low, whereas that of the positively charged species below $\mathrm{pH} 12.5$ was high. Therefore, it was concluded that organic carbon is mainly adsorbed onto the surface of mortar via silanol groups electrostatically, and so sorption will depend on the ionic speciation of the organic carbon species in aqueous solution.

\subsubsection{Inorganic Carbon}

Inorganic ${ }^{14} \mathrm{C}$ sorption by cementitious materials can be roughly divided into two reactions; (i) adsorption onto a positive site and (ii) precipitation. Noshita et al. [35] have suggested that ${ }^{14} \mathrm{CO}_{3}{ }^{2-}$ was sorbed onto the cement surface electrostatically, due to the reaction between $\mathrm{SiO}_{2}$ and $\mathrm{CaO}$ contained in the cement. That is, $\mathrm{SiO}_{2}$ was originally anionic $\left(\mathrm{SiO}^{-}\right)$, but became cationic through interaction with $\mathrm{Ca}^{2+}$. The ${ }^{14} \mathrm{C}$ $\mathrm{K}_{\mathrm{d}}$ was increased from 2,000 to 7,000 $\mathrm{ml} \mathrm{g}^{-1}$ by adding $\mathrm{SiO}_{2}$ to OPC. Banba et al. [36] also suggested that this immobilisation was also by adsorption onto colloidal compounds in cement.

Noshita et al. [15] found that $\mathrm{CO}_{3}{ }^{2-}$ it sorbed onto calcium silicate compounds with lower $\mathrm{Ca}: \mathrm{Si}$ ratios if the bulk solution was in $\mathrm{NaOH}(\mathrm{aq})$, but that sorption was less in bulk $\mathrm{Ca}(\mathrm{OH})_{2}$ solution This indicated that formation of $\mathrm{CaCO}_{3}$ may affect $\mathrm{R}_{\mathrm{d}}$ values, although the initial carbonate concentration was adjusted to below its maximum solubility. In $\mathrm{Ca}(\mathrm{OH})_{2}$ solution, the order of sorption was gibbsite $>$ brucite $>$ portlandite, which may reflect the tendency of $\mathrm{CaCO}_{3}$ to flocculate and precipitate as colloids. 


\subsubsection{Chlorine}

Several authors, e.g. Brown et al. [37] and Damidot et al. [38] have characterised the formation of basic chlorides, (hydr)oxychlorides, in cement systems. The interaction of $\mathrm{Cl}^{-}$ions with a cement matrix depends on several parameters. Chloride can react with unhydrated aluminate phases to form new compounds such as Friedel's salt [37] [38][39]. Sorption, or secondary phase formation, depends on the type of binder and the nature of the cations in the pore solution [40], [41], [42], [43] as well as on the pore solution concentration and composition. For example, the amount of bound $\mathrm{Cl}^{-}$ added as $\mathrm{CaCl}_{2}$ has been found to be significantly higher than for $\mathrm{Cl}^{-}$added as $\mathrm{NaCl}$ [44] [45], but the reason for this is not clear. It has been suggested that $\mathrm{CaCl}_{2}$ interacts with $\mathrm{Ca}(\mathrm{OH})_{2}$ at low temperatures, and high $\mathrm{Cl}^{-}$concentrations, to give $\mathrm{CaO}-$ $\mathrm{CaCl}_{2}-\mathrm{H}_{2} \mathrm{O}$ complex salts with varying compositions [44]. Tang et al. [14] observed that the $\mathrm{Cl}^{-}$binding capacity of HCP strongly depends on the content of CSH gel.

Several possible states of $\mathrm{Cl}^{-}$in the hydration of tricalcium silicate in the presence of $\mathrm{CaCl}_{2}$ have been suggested [46] These include a chemisorbed [46] $\mathrm{Cl}^{-}$layer on the surface of $\mathrm{CSH}$, in the interlayer space and incorporated in the CSH lattice. Beaudoin et al. have suggested that most of the chloride ions are chemisorbed on the surface of hydrated $\mathrm{C}_{3} \mathrm{~S}[47]$.

${ }^{35} \mathrm{Cl}$ NMR relaxation methods [48] indicated that the majority of the sorbed $\mathrm{Cl}^{-}$near the surfaces of solid phases such as portlandite and jennite was in a solution-like environment, and was in rapid exchange with free $\mathrm{Cl}^{-}$in the bulk solution. The total amount of sorbed $\mathrm{Cl}^{-}$on jennite was substantially greater than could be accommodated by coordination directly to the solid surfaces and the amount predicted to exist in the Stern and diffuse layers based on Gouy-Chapman calculations. The authors postulated that this excess was probably due primarily to formation of metal complexes or ion pairs.

\subsubsection{Iodine}


The mechanism of $\mathrm{I}^{-}$uptake in cement hydrate phases is sorption and/or incorporation according to Glasser et al. [49]. Precipitation as a simple iodide salt is most unlikely, because its salts are either too soluble, or else sufficient insolubilising cations are not normally present in cements (e.g., $\mathrm{Ag}^{+}, \mathrm{Pb}^{2+}$ ) [49].

Long-term experiments have shown that $\mathrm{I}^{-}$sorption increases with increasing $\mathrm{Ca}: \mathrm{Si}$ ratio in $\mathrm{CSH}$ gels (in agreement with [6]), despite increased competition from $\mathrm{OH}^{-}$for sorption sites at higher $\mathrm{Ca}: \mathrm{Si}$ ratios [15] [49], suggesting that $\mathrm{I}^{-}$was sorbed electrostatically. $\mathrm{AF}_{\mathrm{t}}$ behaved similarly to high $\mathrm{Ca}: \mathrm{Si}$ ratio $\mathrm{CSH}$. $\mathrm{AF}_{\mathrm{m}}$ however, has been shown to be a much more efficient scavenger with $70-80 \%$ removal from $10^{-3}$ mol dm ${ }^{-3}$ solutions.

Iodide sorption on three commercial alumina cements mixed with $\mathrm{CaSO}_{4}$ and/or $\mathrm{Ca}(\mathrm{OH})_{2}$ was investigated by Toyohara et al. [50] [51]. The highest sorption was obtained with $\mathrm{CaSO}_{4}$ added to alumina cement to a $\mathrm{SO}_{4}$ :Ca mole ratio of 0.16 . The $\mathrm{I}^{-}$ replaced the $\mathrm{OH}^{-}$in $4 \mathrm{CaO} \cdot \mathrm{Al}_{2} \mathrm{O}_{3} \cdot 13 \mathrm{H}_{2} \mathrm{O}$ to form the new hydrate $3 \mathrm{CaO} \cdot \mathrm{Al}_{2} \mathrm{O}_{3} \cdot \mathrm{CaI}_{2} \cdot 12 \mathrm{H}_{2} \mathrm{O}$. The results of sorption and desorption experiments showed that $\mathrm{I}^{-}$sorption was reversible and independent of concentration up to $1 \times 10^{-2} \mathrm{~mol} \mathrm{dm}-$ 3 .

$\mathrm{CSH}$ has a much stronger affinity for iodate than iodide. This is probably due to the more complex structure of the iodate anion with the surrounding oxygens acting as bridges with the complex CSH substrate. Slight desorption occurs with time, which is thought to be due to occlusion of aqueous iodate in $\mathrm{CSH}$ followed by diffusion of the excess back to solution. A similar phenomenon has been found for sulphate in CSH [44].

\subsubsection{Lead}

Glasser [52] suggests that $\mathrm{Pb}$ will generally replace $\mathrm{Ca}$ in cement hydrate phases. Moulin et al. [53] found that whereas $\mathrm{Pb}$ shows a poor affinity to calcium aluminate phases (due to precipitation of $\mathrm{PbO}$ ), it was strongly retained by hydrated phases coming from $\mathrm{C}_{4} \mathrm{AF}$ hydration, and that the $\mathrm{Pb}$ was linked to silica tetrahedra. The authors attributed this strong retention of lead to the hydrated "ferrite" phase. 
Sorption isotherms of $\mathrm{Pb}(\mathrm{II})$ carried out on $\mathrm{C}_{3} \mathrm{~S}$ and $\mathrm{CSH}$ showed that $\mathrm{Pb}$ has differing affinities for calcium silicate in a concentration range lower than the saturation concentration value of $\mathrm{PbO}$ [54]. Structural retention mechanisms have been attributed to $\mathrm{Q}_{1 \mathrm{Mc}}$ sites involving Si-O-Pb bonds by Rose et al. [55].

Johnson et al. [56] have shown that a relatively high proportion of $\mathrm{Pb}$ precipitated out on the cement matrix, rather than in the precipitated layer as was the case for $\mathrm{Cr}, \mathrm{Cu}$ and $\mathrm{Zn}$. It is possible that isomorphic substitution of $\mathrm{Ca}^{2+}$ by $\mathrm{Pb}^{2+}$ (ionic radii 1.00 and $1.17 \mathrm{~A}$, respectively) had taken place in the cement matrix.

An investigation by Coleman et al. [57] into the interactions of aqueous $\mathrm{Pb}^{2+}$ ions with crushed concrete fines $(\mathrm{CCF})$, showed that the surface of $\mathrm{Pb}-\mathrm{CCF}$ was generally composed of a reticular, lead-bearing, calcium silicate network and, occasionally, lead-bearing, calcium-rich, distorted polygons. Removal of $\mathrm{Pb}^{2+}$ from solution took place by diffusion into the cement matrix. The authors postulated that the underlying mechanism was isomorphic substitution by $\mathrm{Pb}^{2+}$ for $\mathrm{Ca}^{2+}$ in the $\mathrm{CSH}$. The rare, calcium-rich, heavy metal-bearing polygons observed on the surfaces of each of the recovered CCF specimens were suggested to be re-precipitated portlandite crystals, distorted from their normal hexagons by the inclusion of $\mathrm{Pb}^{2+}$ ions.

Many authors have examined the influence of $\mathrm{Pb}$ on the hydration properties of cement. Thomas et al. [58] observed retardation of hydration, due to a rapid precipitation of basic lead compounds. The precipitate that coated the surface of the cement grains was essentially formed of a colloidal gelatinous material. According to Cartledge et al. [59], coatings, which hinder cement hydration, can be formed by lead hydroxide, sulphate, and nitrate mixed salts. Cocke et al., [60] [61] [62] have argued that the coatings act as diffusional barriers to water. A charge dispersal model in which the calcium ions induce a charge reversal of the silicate surface allowing $\mathrm{Pb}(\mathrm{OH})_{3}{ }^{-}$ions to be adsorbed has been proposed for retardation by Yousuf et al. [63] and Asavapisit et al. [64]. On the other hand, Ortego et al. [65] have suggested that the presence of lead could result in a slight enhancement of silicate polymerisation. 
Mattus et al. [66] have suggested that retardation is due to precipitation of sparingly soluble compounds onto the surface of silicate phases, thus preventing their access to water. However, the retardation effect is concentration-dependent, so that $\mathrm{Pb}$ has been shown to be a set accelerator in some cases [67].

\subsubsection{Selenium}

Selenate sorbs via weakly bonded outer-sphere complexes [68]. Kumarathasan et al. [30] and Baur et al. [68] have reported the replacement of $\mathrm{SO}_{4}{ }^{2-}$ by selenate in ettringite, and this has also been observed in 'monosulphate' which has a crystalline layer structure derived from that of $\mathrm{Ca}(\mathrm{OH})_{2}$ by the ordered replacement of one $\mathrm{Ca}^{2+}$ ion in three with $\mathrm{Al}^{3+}$ or $\mathrm{Fe}^{3+}$. These layers alternate with ones containing anions, which balance the charge (e.g. $\mathrm{SO}_{4}{ }^{2-}, \mathrm{OH}^{-}$, etc.) and $\mathrm{H}_{2} \mathrm{O}$. The composition is $\left[\mathrm{Ca}_{2}(\mathrm{Al}, \mathrm{Fe})(\mathrm{OH})_{6}\right] \cdot \mathrm{Z} \cdot x \mathrm{H}_{2} \mathrm{O}$, where $\mathrm{Z}$ represents the interlayer anion. [31] [69] [70] [71].

Solem-Tishmack et al. [72] have interpreted the more efficient retention of selenite over selenate by the formation of selenite ettringite in cementitious material. However, $\mathrm{CaSeO}_{3}$ precipitation seems the more likely reason for the retention [65].

Bonhoure et al. [73] have shown that Se redox reactions do not influence uptake processes in cementitious systems. EXAFS spectra of $\mathrm{Se}(\mathrm{IV})$ and $\mathrm{Se}(\mathrm{VI})$ bound to $\mathrm{CH}, \mathrm{AFt}, \mathrm{AFm}$ and $\mathrm{CSH}$ were similar to those of $\mathrm{SeO}_{4}{ }^{2-}-$ and $\mathrm{SeO}_{3}{ }^{2-}$ in solution, indicating a "solution-like" coordination environment on uptake by cement minerals. The results suggested that the coordination spheres of selenate and selenite are maintained on immobilisation.

\subsubsection{Sulphate}

Kalousek [1] proposed that $\mathrm{SO}_{4}{ }^{2-}$ ions present in cement eventually enter CSH and experimental studies [74] [75] have demonstrated that sulphate can bind to CSH. Nachbaur [76] showed that the mechanism of sulphate binding was a surface

phenomenon. The main quantitative results were obtained by Divet et al. [77], who found that sulphate sorption on CSH fitted a Langmuir isotherm, and that sorption 
increased with $\mathrm{pH}$ and temperature, and that sulphate binding increases with the $\mathrm{Ca}: \mathrm{Si}$ ratio of $\mathrm{CSH}$.

\subsubsection{Tin}

A study by Seby et al. [78] showed a strong uptake of Sn(IV) by HCP at $\mathrm{pH} 13.3$ at Sn concentrations well below the solubility limit of Ca-stannate. Bonhoure et al. [79] have suggested that $\mathrm{CSH}$ phases may not be the uptake-controlling phase in the cement matrix. An alternative model was proposed [79] on the assumption that ettringite is the uptake controlling phase. A study of Sn immobilisation by cement and CSH by Wieland et al. [27] showed that, on HCP, sorption was linear up to a maximum equilibrium concentration of about $8 \times 10^{-7} \mathrm{~mol} \mathrm{dm}^{-3}$. Above this immobilisation was due to the formation of a Ca-stannate precipitate, often described in the literature as $\mathrm{CaSn}(\mathrm{OH})_{6}$.

\subsection{Transition Elements}

\subsubsection{Cadmium}

Bonen et al. [80] have reported ettringite accommodating $\mathrm{Cd}^{2+}$ at the $\mathrm{M}^{2+}$ site in the crystal structure. Polettini et al., [81] found chemical immobilisation of Cd within $\mathrm{CSH}$ at $\mathrm{pH}>10$. Furthermore, the low aqueous $\mathrm{Cd}$ concentrations found at high $\mathrm{pH}$ may account for its immobilisation within portlandite, as $\mathrm{Cd}$ is known to provide nucleation sites both for CSH and portlandite [66].

\subsubsection{Chromium}

Chromium's oxidation state and its immobilisation by cements are closely related. Kumarathasan et al. [30] has reported the replacement of $\mathrm{SO}_{4}{ }^{2-}$ by chromate in ettringite. Moulin et al. [53] have observed interactions between $\mathrm{Cr}$ and hydrated cement phases. It was found that $\mathrm{Cr}$ showed a strong affinity for hydrated $\mathrm{C}_{4} \mathrm{AF}$ "ferrite" phases. $\mathrm{Cr}(\mathrm{III})$ is structurally incorporated by hydrogarnet phases, but $\mathrm{Cr}(\mathrm{VI})$ only showed an affinity for hydrated calcium aluminate phases. For $\mathrm{Cr}(\mathrm{III})$, whatever 
the cement phases studied, a hydrogarnet phase of variable composition was formed. $\mathrm{Cr}(\mathrm{VI})$ was weakly retained by calcium silicate, but more by calcium aluminate and aluminoferrite. According to other results [82] [83] [84], ion-exchange between $\mathrm{CrO}_{4}{ }^{2-}$ and $\mathrm{OH}^{-}$in the $\mathrm{AF}_{\mathrm{m}}$ phase are responsible for immobilisation.

According to Polettini et al. [81] Cr(III) is known to be able to increase the amount of heat liberated during early hydration, promoting the formation of ettringite crystals, probably by reducing the degree of supersaturation [85]. There is evidence for the ability of $\mathrm{CSH}$ to incorporate $\mathrm{Cr}^{3+}$ ions through $\mathrm{Si}$ substitution in poorly crystalline structures [81]. Calcium aluminate hydrate phases can also be formed where octahedrally coordinated aluminium is partly replaced by $\mathrm{Cr}(\mathrm{III})$ [81].

\subsubsection{Cobalt}

Bonen et al. [80] have reported ettringite accommodating $\mathrm{Co}^{2+}$ at the $\mathrm{M}^{2+}$ site in the crystal structure, while Noshita et al. showed that it was strongly sorbed onto CSH gel $[20]$.

Vespa et al. [86] found that, for samples prepared in air, Co(II) is oxidized to Co(III) after $1 \mathrm{~h}$ of hydration time and that the relative amount of Co(III) increased with hydration time. Co(II) was predominately present as a Co-hydroxide-like phase and/or Co-phyllosilicates, whereas $\mathrm{Co}$ (III) tended to be incorporated into a $\mathrm{CoOOH}$ like phase and/or Co-phyllomanganates. Samples prepared in the absence of oxygen revealed solely the presence of $\mathrm{Co}(\mathrm{II})$, indicating that oxygen plays an important role in Co oxidation in cement.

\subsubsection{Copper}

Johnson et al. [56] have shown that precipitation, in addition to lowering solubility at elevated $\mathrm{pH}$, is responsible for the immobilisation of $\mathrm{Cu}$. Analysis of $\mathrm{Cu}$-containing crystals showed a $\mathrm{Ca}$ to $\mathrm{Cu}$ molar ratio of 1:11. Coleman et al.'s [57] study of sorption onto crushed concrete fines (CCF) showed 2 distinct $\mathrm{Cu}$-bearing phases on the surface of $\mathrm{Cu}-\mathrm{CCF}$, a $\mathrm{Cu}$-rich foliaceous mass and rare, $\mathrm{Cu}$-bearing, Ca-rich, distorted polygons. The principal mechanism of $\mathrm{Cu}$ uptake was precipitation of the 
foliated crystals onto the surface. No appreciable diffusion of $\mathrm{Cu}^{2+}$ into the cement matrix was observed.

\subsubsection{Iron}

In 1952, Kalousek proposed that all $\mathrm{Fe}^{3+}$ ions present in cement eventually enter CSH [1]. Copeland et al. [87] provided some support to this theory by suggesting that two $\mathrm{Fe}^{3+}$ atoms replace one calcium and one silicon.

\subsubsection{Mercury}

Poon et al. [88] have produced evidence of $\mathrm{Hg}$ immobilisation by ettringite.

\subsubsection{Molybdenum}

$\mathrm{Mo}(\mathrm{VI})$ can be immobilised in $\mathrm{HCP}$ as both $\mathrm{CaMoO}_{4}$, and as a Mo-substituted $\mathrm{AF}_{\mathrm{m}}$ phase [2].

\subsubsection{Nickel}

Bonen et al. [80] report ettringite accommodating $\mathrm{Ni}^{2+}$ at the $\mathrm{M}^{2+}$ site in the crystal structure. Ni sorbed onto calcium silicates was reported by Noshita et al. [15] showed no dependence on $\mathrm{Ca}: \mathrm{Si}$ ratios, eliminating electrostatic adsorption as a mechanism. Coprecipitation or surface complexation via the hydroxyl group have been suggested [89] [90]. Ni has also been found highly sorbed onto hydroxides, probably due to coprecipitation or surface complexation [89] [90] [91]. This finding contradicts the suggestion of an adsorption-type uptake process. Several authors have noted that there is evidence for a solubility-controlled uptake process [92] [93] [94].

Johnson et al. [56] found that precipitation mechanisms in addition to the reduction in solubility at elevated $\mathrm{pH}$, are responsible for $\mathrm{Ni}$ immobilisation. Analysis showed a $\mathrm{Ca}$ :Ni molecular ratio of 1.10 in the botryoidal Ni-containing precipitate. Scheidegger et al. [92] showed that mixed Ni-Al layered double hydroxides (LDH) may form in cement systems, and thus, Ni-Al LDHs are regarded as solid phases being potentially 
present in the waste matrix and governing nickel uptake, this has been confirmed by Vespa et al. [95]. The work of Johnson et al., [93] however, indicates that $\mathrm{Ni}_{4} \mathrm{Al}_{2}(\mathrm{OH})_{12} \mathrm{CO}_{3} \cdot 2 \mathrm{H}_{2} \mathrm{O}$, which has a LDH-type structure, is unlikely to account for the limited solubility of $\mathrm{Ni}$ in cement systems.

\subsubsection{Vanadium}

Kumarathasan et al. [30] has reported the replacement of $\mathrm{SO}_{4}{ }^{2-}$ by vanadate in ettringite.

\subsubsection{Zinc}

Bonen et al. [80] report ettringite incorporating $\mathrm{Zn}^{2+}$ at the $\mathrm{M}^{2+}$ site. Moulin et al. [53] found interactions between hydrated cement phases and $\mathrm{Zn}$, and concluded that $\mathrm{Zn}$ showed a strong affinity for hydrated ferrite phases and that it was linked to the silica tetrahedra of CSH. From sorption experiments by Ludwig et al. [94], it appears that $\mathrm{Zn}$ is strongly retained by $\mathrm{CSH}$. This retention has been attributed to the linkage of tetrahedral $\mathrm{Zn}$ to $\mathrm{CSH}$ tetrahedral silicate chains [54] [82].

Ziegler et al. [96] [97] found that at high $\mathrm{Zn}(\mathrm{II})$ concentrations $\left(>1 \mathrm{mmol} \mathrm{dm}^{-3}\right)$, the precipitation of $\beta_{2}-\mathrm{Zn}(\mathrm{OH})_{2}\left(<\mathrm{pH}\right.$ 12) and calcium zincate $\mathrm{Zn}_{2} \mathrm{Ca}(\mathrm{OH})_{6} .2 \mathrm{H}_{2} \mathrm{O}(>\mathrm{pH}$ 12) occurred, but do not indicate the concentration at which precipitation begins. Surface precipitation was not found. $\mathrm{Zn}$ was observed to incorporate into the CSH(I) particles, but it did not appear to substitute for calcium or silicon.

XAFS spectra of the $\mathrm{Zn}(\mathrm{II})$ equilibrated with $\mathrm{CSH}(\mathrm{I})$ suggested tetrahedral coordination of $\mathrm{Zn}(\mathrm{II})$ by 4 oxygen atoms in the atomic shell. This coordination environment was related by the author to the structure of hemimorphite, a naturally occurring zinc silicate, and/or the presence of $\gamma-\mathrm{Zn}(\mathrm{OH})_{2}$.

Johnson et al. [56] found that cubic crystals observed on concrete particles following contact with $\mathrm{Zn}^{2+}$ solution were found to be calcium-rich, whereas the underlying precipitate was Zn -rich. Coleman et al's study [57] of CCF sorption showed a Znrich porous 'cancellated' network and occasional, zinc-bearing, calcium-rich, 
distorted polygons over which a further diffuse deposit had formed. The authors concluded that the mechanism of uptake of Zn by CCF was characterised by 3 stages. Firstly, deposition of a $\mathrm{Zn}$-rich precipitate on the surface of CCF, a few microns in depth. Secondly, the formation of a second deposit of around $10 \mu \mathrm{m}$ and, thirdly, a final superficial precipitate. The authors postulated that the different precipitation processes were mediated by $\mathrm{pH}$ and the concentration and speciation of $\mathrm{Zn}^{2+}$ ions in solution. $\mathrm{Zn}^{2+}$ ions did not appear to have penetrated the cement matrix to any appreciable extent.

Zinc has been reported as causing a substantial retardation in the setting of cement by formation of a protective layer over the cement grains. In the case of $\mathrm{C}_{3} \mathrm{~S}$, Ortego et al. [65] demonstrated that polymerisation was retarded by its presence. Arliguie et al. [98] and Gawlicki et al. [99] have suggested that this retardation results from precipitation of an amorphous layer of $\mathrm{Zn}(\mathrm{OH})_{2}$ onto the anhydrous grains, but that the hydration process could be restarted once the $\mathrm{Ca}$ concentration in solution was sufficient to induce crystallisation of calcium zinc hydroxide. Yousuf et al. [63] [100] suggest that surface formation of $\mathrm{CaZn}_{2}(\mathrm{OH})_{6} \cdot 2 \mathrm{H}_{2} \mathrm{O}$ prevented the necessary material transport for the hydration of $\mathrm{C}_{3} \mathrm{~S}$. A similar process was proposed by Asavapisit et al. [64] for clinker particles. Others studies [94] [101] seem to indicate that $\mathrm{Zn}$ might be incorporated into the CSH framework.

\subsection{Lanthanides}

\subsubsection{Europium}

Tits et al. [25] described the adsorption of Eu(III) on CSH. The results showed that the sorption process controlling the retention of $\mathrm{Eu}$ is fast indicating that uptake is probably controlled by an adsorption process. Very high sorption distribution ratios in the range of 105 to $106 \mathrm{dm}^{3} \mathrm{~kg}^{-1}$ were found.

The sorption mechanisms of $\mathrm{Eu}$ on $\mathrm{CSH}$ phases of hydrated cement were investigated by Pointeau et al. [102]. The CSH phases, to simulate long-term behaviour, were chosen to have a $\mathrm{Ca}: \mathrm{Si}$ ratio corresponding to aged cements and, at the same time, 
equal to the ratio of 0.83 in tobermorite. Eu was not precipitated in solution despite its low solubility limit. It was strongly retained on the CSH (more than $99.8 \%$ sorbed). Two main sorption sites were characterised. One site, with a long lifetime $(>1 \mathrm{~ms})$, was interpreted as Eu substituting for $\mathrm{Ca}$ in the framework of the CSH. Another, with a shorter lifetime $(>0.4 \mathrm{~ms})$, was interpreted as a site with a high hydroxylated environment, but one that is less than that of $\operatorname{Eu}(\mathrm{OH})_{3}$, which corresponded to surface complexation or precipitation at around $10^{-10} \mathrm{~mol} \mathrm{dm}^{-3}$. The authors thought it reasonable that Eu might be withdrawn from the liquid phase by a simple precipitation process, due to its low solubility limit, but results showed that this was not the case. It was suggested that the presence of CSH causes a dragging force, which prevents normal precipitation. Tits et al. [22] have corroborated this.

Eu LIII-edge EXAFS spectra collected by Schlegel et al. [103] on samples of Eu sorbed on, or coprecipitated in, $\mathrm{CSH}$ differed from that of $\mathrm{Eu}(\mathrm{OH})_{3}(\mathrm{~s})$ expected to precipitate under the $\mathrm{pH}$ conditions of $\mathrm{CSH}$ waters, ruling out precipitation of pure hydroxide phases, despite total Eu concentrations well above supersaturating conditions. These results indicated that the sorbed or coprecipitated Eu was located at Ca structural sites in a CSH-like environment. Kinetics and spectroscopic results were consistent with either Eu diffusion within CSH particles, or precipitation of Eu with $\mathrm{Ca}$ and $\mathrm{Si}$, creating a $\mathrm{CSH}-$ like solid phase.

\subsection{Group II Elements}

\subsubsection{Strontium}

The behaviour of $\mathrm{Sr}$ in cements might be expected to mirror that of $\mathrm{Ca}$. However, it is more soluble in $\mathrm{NaOH}$ or $\mathrm{KOH}$, to the extent that $\mathrm{Sr}(\mathrm{OH})_{2}$ precipitation in cements is unlikely [104]. OPC is a very efficient scavenger for Sr: Atkins et al. found that $95 \%$ of ${ }^{89} \mathrm{Sr}$ was associated with the solid phase. The hydration products of $\mathrm{C}_{4} \mathrm{AF}$ and $\mathrm{C}_{3} \mathrm{~A}$ can also completely accommodate low Sr levels. At $25^{\circ} \mathrm{C}$, and in the absence of sulphate, the authors suggested that the major product was probably $\mathrm{C}_{4} \mathrm{AH}_{13}$ [104]. $\mathrm{CSH}$ gels of $\mathrm{Ca}: \mathrm{Si}$ ratio 1.7 and $\mathrm{Ca}(\mathrm{OH})_{2}$, appear to be less efficient sorbers, but higher sorption might be expected at lower Ca:Si ratios. This might be expected for 
$\beta C_{2} S$, since it hydrates slowly relative to the other clinker phases, but $C_{3} S$ hydrates at a similar rate and yet only $34 \%$ of the strontium was solid-associated.

Possible substitution of $\mathrm{Sr}$ in $\mathrm{C}_{3} \mathrm{AH}_{6}$ has been studied [104]. Analytical electron microscopy (AEM) showed the mean $\mathrm{SrO}: \mathrm{Al}_{2} \mathrm{O}_{3}$ mole ratio was 0.052 , equivalent to ca. $1.6 \%$ substitution of $\mathrm{Sr}$ for $\mathrm{Ca}$. All the $\mathrm{Sr}$ in the system had been taken up in the solid phase. Higher levels of substitution are probably achievable in more Sr-rich starting materials, e.g. the phase $\mathrm{Sr}_{4} \mathrm{AH}_{6}$ has been shown to exist.

The major sink for $\mathrm{Sr}$ was probably the calcium aluminium (sulphate) hydrates. Appreciable substitution of strontium in $\mathrm{AF}_{\mathrm{t}}$ and $\mathrm{C}_{3} \mathrm{AH}_{6}$ has been demonstrated, and was thought to be likely by the authors in $\mathrm{AF}_{\mathrm{m}}$-type phases [104]. Therefore, cements high in $\mathrm{Ca}$ and $\mathrm{Al}$, such as high alumina cement (HAC), will have the best 'sorption' characteristics for Sr. Leach experiments on Sr loaded pastes, in conjunction with consideration of the effect of carbonation, have indicated coprecipitation of $\mathrm{SrCO}_{3}$ to be a solubility-limiting process for release. An ettringite analogue with Sr replacing Ca has been reported [105].

\subsubsection{Barium}

Glasser [52] has suggested that $\mathrm{Ba}$ will generally replace $\mathrm{Ca}$ in cement hydrate phases.

\subsection{Group III Elements}

\subsubsection{Aluminium}

Kalousek has proposed that all $\mathrm{Al}^{3+}$ ions present in cement eventually enter CSH [1]. Copeland et al. [87] concluded that $\mathrm{Al}^{3+}$ enters the CSH by joining with a proton to replace an $\mathrm{Si}$ atom or by joining with another $\mathrm{Al}^{3+}$ ion to replace $3 \mathrm{Ca}^{2+}$ ions.

\section{Summary}

The various immobilisation mechanisms identified have been summarised in table 1 . 


\begin{tabular}{|c|c|c|c|}
\hline Element & $\begin{array}{c}\text { Solid } \\
\text { Studied }\end{array}$ & Mechanism & Reference \\
\hline Group 1 & $\mathrm{CSH}$ & Electrostatic Sorption $^{1}$ & {$[3]$} \\
\hline Group 1 & $\mathrm{CSH}$ & Electrostatic Sorption to silanol $^{1}$ & {$[4]$} \\
\hline $\mathrm{Al}$ & $\mathrm{CSH}$ & Substitution for $\mathrm{Si}$ & [87] \\
\hline $\mathrm{Am}$ & Concrete & Mineralogical control & [13] \\
\hline $\mathrm{Am}$ & Concrete & Surface area control & {$[13]$} \\
\hline $\mathrm{Am}$ & OPC & Via hydroxide species & [19] \\
\hline As & OPC & Sorption onto CSH & {$[32]$} \\
\hline As & OPC & $\mathrm{SO}_{4}{ }^{2-}$ substitution in ettringite & {$[32][30]$} \\
\hline As & OPC & Ca-As compound formation & {$[32][33]$} \\
\hline $\mathrm{Ba}$ & $\mathrm{CSH}$ & Substitution for $\mathrm{Ca}$ & {$[52]$} \\
\hline $\mathrm{C}(\mathrm{Org})$ & Mortar & Electrostatic Sorption $^{1}$ & {$[34]$} \\
\hline $\mathrm{Cd}$ & $\mathrm{CSH}$ & $\begin{array}{l}\text { Immobilisation within } \\
\text { CSH structure }\end{array}$ & {$[81]$} \\
\hline $\mathrm{Cl}^{-}$ & $\mathrm{HCP}$ & Formation of $\mathrm{CaO}-\mathrm{CaCl}_{2}-\mathrm{H}_{2} \mathrm{O}$ & {$[44]$} \\
\hline $\mathrm{Cl}^{-}$ & Concrete & $\begin{array}{c}\text { Chemisorbed layer on the } \\
\text { surface of CSH }\end{array}$ & {$[46]$} \\
\hline $\mathrm{Cl}^{-}$ & $\mathrm{CSH}$ & $\begin{array}{l}\text { Chemisorbed on hydrated } \mathrm{C}_{3} \mathrm{~S} \\
\text { surface }\end{array}$ & {$[47]$} \\
\hline $\mathrm{Cl}^{-}$ & $\begin{array}{l}\text { (Synthetic) } \\
\text { CSH }\end{array}$ & Freidel's salt formation & {$[37][38][39]$} \\
\hline $\mathrm{Cm}^{3+}$ & $\mathrm{CSH}$ & Incorporation in $\mathrm{CSH}$ & [21] [22] \\
\hline $\mathrm{CO}_{3}{ }^{2-}$ & $\mathrm{HCP}$ & Precipitation $^{2}$ & {$[15]$} \\
\hline $\mathrm{CO}_{3}{ }^{2-}$ & Cement & Adsorption on colloids & {$[36]$} \\
\hline $\mathrm{CO}_{3}{ }^{2-}$ & $\mathrm{HCP}$ & $\begin{array}{l}\text { Electrostatic adsorption onto a } \\
\text { positive site }\end{array}$ & {$[37]$} \\
\hline $\mathrm{Cr}(\mathrm{III})$ & Hydrogarnet & Incorporation by hydrogarnet & {$[53]$} \\
\hline $\mathrm{Cr}(\mathrm{III})$ & $\mathrm{CSH}$ & Si substitution in $\mathrm{CSH}$ & {$[81]$} \\
\hline $\mathrm{Cr}(\mathrm{III})$ & $\mathrm{CSH}$ & $\begin{array}{c}\text { Al substitution in } \\
\text { Ca Aluminate hydrate }\end{array}$ & [81] \\
\hline $\mathrm{Cr}(\mathrm{VI})$ & Aluminate & Ion-exchange with $\mathrm{OH}^{-}$ & {$[82][83][84]$} \\
\hline $\mathrm{Cr}(\mathrm{VI})$ & $\mathrm{OPC}$ & $\mathrm{SO}_{4}{ }^{2-}$ substitution in ettringite & {$[30]$} \\
\hline Cs & $\begin{array}{c}\mathrm{CSH} \\
\text { Aluminate }\end{array}$ & & {$[5]$} \\
\hline Cs & $\mathrm{CSH}$ & Electrostatic Sorption $^{1}$ & {$[15]$} \\
\hline Cs & $\mathrm{CSH}$ & & {$[6]$} \\
\hline $\mathrm{Cs}$ & $\mathrm{CSH}$ & Breakage of & {$[3]$} \\
\hline
\end{tabular}




\begin{tabular}{|c|c|c|c|}
\hline & & silicate chain & \\
\hline Cs & Cement & $\begin{array}{l}\text { Inside agglomerated } \\
\text { silica particles }\end{array}$ & {$[16]$} \\
\hline $\mathrm{Cu}$ & $\mathrm{CCF}$ & Precipitation $^{3}$ & {$[56][57]$} \\
\hline $\mathrm{Eu}$ & $\mathrm{CSH}$ & Adsorption & {$[25]$} \\
\hline $\mathrm{Eu}$ & $\mathrm{CSH}$ & $\begin{array}{l}\text { Surface complexation or } \\
\text { precipitation }^{4}\end{array}$ & {$[102][22]$} \\
\hline $\mathrm{Hg}$ & Ettringite & & {$[88]$} \\
\hline $\mathrm{I}^{-}$ & Alumina Cement & Replacement of $\mathrm{OH}^{-}$ & {$[50]$} \\
\hline $\mathrm{I}^{-}$ & $\mathrm{CSH}$ & Electrostatic Sorption $^{1}$ & {$[15]$} \\
\hline $\mathrm{I}^{-}$ & $\mathrm{OPC}$ & Electrostatic Sorption $^{1}$ & {$[49]$} \\
\hline $\mathrm{I}^{-}$ & OPC & Incorporation & [49] \\
\hline $\mathrm{Mo}(\mathrm{VI})$ & $\mathrm{HCP}$ & $\begin{array}{c}\mathrm{CaMoO}_{4} \text { and Mo-substituted } \\
\mathrm{AF}_{\mathrm{m}} \text { phase }\end{array}$ & {$[2]$} \\
\hline $\mathrm{Na}$ & $\mathrm{CSH}$ & Substitution & {$[17]$} \\
\hline $\mathrm{Na}$ & $\mathrm{CSH}$ & Ion exchange & {$[18]$} \\
\hline $\mathrm{Ni}$ & $\mathrm{CSH}$ & & {$[15]$} \\
\hline $\mathrm{Ni}$ & $\mathrm{CSH}$ & $\begin{array}{c}\text { Coprecipitation or } \\
\text { surface complexation }\end{array}$ & {$[90]$} \\
\hline $\mathrm{Ni}$ & $\mathrm{HCP}$ & $\begin{array}{c}\text { Coprecipitation or } \\
\text { surface complexation }\end{array}$ & {$[56][91]$} \\
\hline $\mathrm{Ni}$ & $\mathrm{HCP}$ & Formation of LDH & {$[92]$} \\
\hline $\mathrm{Np}$ & OPC & Sorption followed by reduction & {$[23]$} \\
\hline $\mathrm{Pb}$ & $\mathrm{CSH}$ & $\begin{array}{c}\text { Linked to silica tetrahedra in } \\
\text { ferrite }\end{array}$ & {$[53]$} \\
\hline $\mathrm{Pb}$ & $\mathrm{CSH}$ & Formation of Si-O-Pb bonds & {$[54][55]$} \\
\hline $\mathrm{Pb}$ & $\mathrm{CCF}$ & Precipitation $^{5}$ & {$[56]$} \\
\hline $\mathrm{Pb}$ & OPC & Precipitation $^{2}$ & {$[58][59]$} \\
\hline $\mathrm{Pb}$ & $\mathrm{CSH}$ & Sorption of $\mathrm{Pb}(\mathrm{OH})_{3}{ }^{-}$ & {$[63][64]$} \\
\hline $\mathrm{Pb}$ & $\mathrm{CCF}$ & Substitution for $\mathrm{Ca}$ & {$[57]$} \\
\hline $\mathrm{Pu}$ & Concrete & $\begin{array}{l}\text { Preferential on cement } \\
\text { paste over aggregates }\end{array}$ & {$[13]$} \\
\hline $\mathrm{SeO}_{3}{ }^{2-}$ & Ettringite & Formation of $\mathrm{CaSeO}_{3}$ & {$[68]$} \\
\hline $\mathrm{SeO}_{3}{ }^{2-}$ & Ettringite & Electrostatic sorption $^{1}$ & {$[68]$} \\
\hline $\mathrm{SeO}_{4}{ }^{2-}$ & Ettringite & $\begin{array}{l}\text { Substitution for } \mathrm{SO}_{4}^{2-} \text { in } \\
\text { ettringite \& monosulphate }\end{array}$ & {$[69][71]$} \\
\hline $\mathrm{Sn}$ & $\mathrm{CSH}$ & $\begin{array}{c}\text { Ca stannate formation }{ }^{2} \\
\text { Sorption at lower concentrations }\end{array}$ & {$[27]$} \\
\hline $\mathrm{SO}_{4}^{2-}$ & $\mathrm{CSH}$ & Surface sorption & {$[76]$} \\
\hline
\end{tabular}




\begin{tabular}{|l|c|c|c|}
\hline $\mathrm{Sr}$ & $\mathrm{C}_{3} \mathrm{AH}_{6}$ & Substitution for Ca & {$[104]$} \\
\hline $\mathrm{U}(\mathrm{VI})$ & & $\begin{array}{c}\text { Formation of solubility limiting } \\
\text { Phases with Ca and } \mathrm{Si}^{6}\end{array}$ & {$[26]$} \\
\hline $\mathrm{U}(\mathrm{VI})$ & $\mathrm{OPC}$ & Inner sphere interactions $^{6}$ & {$[23]$} \\
\hline $\mathrm{U}(\mathrm{VI})$ & $\mathrm{OPC}$ & $\begin{array}{c}\text { Formation of oligomeric surface } \\
\text { complexes or precipitates }\end{array}$ & {$[23]$} \\
\hline $\mathrm{U}(\mathrm{VI})$ & $\mathrm{HCP} / \mathrm{CSH}$ & Calcium uranate precipitate $^{2}$ & {$[27]$} \\
\hline $\mathrm{U}(\mathrm{VI})$ & $\mathrm{CSH}$ & Sorption $^{-}$ & {$[28]$} \\
\hline $\mathrm{VO}_{3}{ }^{-}$ & $\mathrm{OPC}$ & $\mathrm{SO}_{4}{ }^{2-}$ substitution in ettringite $^{2}$ & {$[30]$} \\
\hline $\mathrm{Zn}$ & $\mathrm{CSH}$ & $\begin{array}{c}\text { Linked to Si } \\
\text { tetrahedra in CSH }\end{array}$ & {$[53][54][82]$} \\
\hline $\mathrm{Zn}$ & $\mathrm{CCF}$ & Precipitation $^{7}$ & {$[56]$} \\
\hline $\mathrm{Zn}$ & Ferrite & $\begin{array}{c}\text { Formation of Fe-O-Zn } \\
\text { bonds in ferrite }\end{array}$ & {$[94]$} \\
\hline $\mathrm{Zn}$ & $\mathrm{CSH}$ & $\begin{array}{c}\text { Precipitation of } \\
\text { zincate phases }\end{array}$ & {$[96]$} \\
\hline
\end{tabular}

${ }^{1}$ Electrostatic mechanism implies opposite charge on the sorbate. ${ }^{2}$ No indication of concentration at which precipitation began. ${ }^{3}[\mathrm{Cu}(\mathrm{aq})]$ after precipitation $=1 \mathrm{ppm} .{ }^{4}$ Solubility limit $\sim 10^{-10} \mathrm{~mol} \mathrm{dm}^{-3-}$ [99]. ${ }^{5}[\mathrm{~Pb}(\mathrm{aq})]$ after precipitation $=9.4 \mathrm{ppm} .{ }^{6}[\mathrm{U}(\mathrm{VI})(\mathrm{aq})]$ after precipitation $=10^{-8}-10^{-9} \mathrm{~mol} \mathrm{dm}^{-3}$. ${ }^{7}[\mathrm{Zn}(\mathrm{aq})]$ after precipitation $=27.5 \mathrm{ppm}$.

\section{Acknowledgements}

The author would like to acknowledge the help of Professor Peter Warwick (Loughborough University), Dr David Bennett (TerraSalus Ltd) and Dr Tim Heath (UK NIREX) for their help with this manuscript, and especially Dr Les Knight (UK NIREX) who supplied the idea and the funding.

\section{$5 \quad$ References}

[1] O.E. Omotoso, G. Ivey, R. Mikula, Containment mechanism of trivalent chromium in tricalcium silicate, J Hazard Mater 60 (1998) 1-28.

[2] F.P. Glasser, Characterisation of the barrier performance of cements, .Mat Res Soc Symp Proc, 713 (2002) 721-732. 
[3] T. Iwaida, S. Nagasaki, S. Tanaka, T. Yaita, Sorption of alkali metal ions onto C-S-H (calcium silicate hydrated phases), Cem Sci Concr Tech 55 (2001) 2126 .

[4] S-Y. Hong, F.P. Glasser, Alkali sorption by C-S-H and C-A-S-H gels. Part II. Role of alumina, Cem Concr Res 32 (2002) 1101-1111.

[5] S. Bagosi, L.J. Csetenyil, Cesium-71 immobilization in hydrated calciumsilicate-aluminate systems, Cem Concr Res 28 (1988) 1753-1759.

[6] S. Aggarwal, M.J. Angus, J. Ketchen, Sorption of Radionuclides onto Specific Mineral Phases Present in Repository Cements, Report AEA Technology NSS/R312 (2000) 1-64.

[7] J.V. Hanna, L.P. Aldridge, E.R. Vance, Cs Speciation in Cements, Mat Res Soc Symp Proc 663 (2001) 89-101.

[8] A. Atkinson, A.K. Nickerson, The diffusion of ions through water-saturated cement, J Mat Sci 19 (1984) 3068-3078.

[9] L.P. Aldridge, R.A. Day, S. Leung, A.S. Ray, M.G. Stevens, R.S. Knight, C.F. Mapson, Cs retention in zeolites immobilized by Portland cement, in: K.L. Scrivener (Ed.), Mechanisms of Chemical Degradation of Cement-Based Systems, E\&FN Spon, London 1997, 358-365.

[10] M.I. Plodinec, Evaluation of ${ }^{137}$ Cs sorbents for fixation in concrete, Report DP-I444, EJ. Du Pont de Nemours and Co., Savannah River Laboratory USA, (1977) 1-25.

[11] A. Atkinson, A.K. Nickerson A.K., Diffusion and Sorption of Cesium, Strontium and Iodine in Water-Saturated Cement, Nucl Tech 81 (1998) 100113. 
[12] M.W. Barnes, B.E. Scheetz, D.M. Roy, The effect of chemically adjusting cement compositions on leachabilities of waste ions, Adv Cer, Nucl Waste Manage 20 (2), (1986) 313-317.

[13] A.T. Jakubick, R.W. Gillham, I. Kahl, M. Robin, Attenuation of Pu, Am, Cs, and Sr mobility in concrete, Mat Res Soc Symp Proc. 84 (1987) 355-368.

[14] S.L. Hoyle, M.W. Grutzeck, Incorporation of caesium by hydrating calcium aluminosilicates. J Am Cer Soc, 72 (10) (1989) 1938-47.

[15] K. Noshita, T. Nishi, T. Yoshida, H. Fujihara, N. Saito, S. Tanaka, Categorization of Cement Hydrates by Radionuclide Sorption Mechanism Mat Res Soc Symp Proc 663 (2001) 115-121.

[16] S.A. Stronach, F.P. Glasser, Modelling the impact of abundant geochemical components on phase stability and solubility of the $\mathrm{CaO}-\mathrm{SiO}_{2}-\mathrm{H}_{2} \mathrm{O}$ system at $25^{\circ} \mathrm{C}: \mathrm{Na}^{+}, \mathrm{K}^{+}, \mathrm{SO}_{4}{ }^{2-}, \mathrm{Cl}^{-}$and $\mathrm{CO}_{3}{ }^{2-}, \mathrm{Adv}$ Cem Res 9 (1997) 167-181.

[17] G. BarNes, A. Katz, Y. Bentur, Y. Peled, Y. Zeiri, Proc Work Mech Model Waste/Cem Interact, Meiringen, Switzerland, (2005) 13.

[18] A.V. Chambers, T.G. Heath, F.M.I. Hunter, M.C. Manning, S.J. Williams, The Effect of Sodium Chloride on the Dissolution of Calcium Silicate Hydrate Gels, Nirex Report, SA/ENN - 0623 (2005) 1-63.

[19] G.M.N. Baston, J.A. Berry, M. Brownsword, T.G. Heath, C. Tweed, S.J. Williams, Sorption of Plutonium and Americium on repository, backfill and geological materials relevant to the JNFL Low-Level Radioactive Waste Repository at Rokkasho-Mura, Mat Res Soc Symp Proc, 353 (1995) 957-964.

[20] K. Noshita, T. Nishi, M. Matsuda , Improved Sorption Ability for radionuclides by Cementitious Materials, WM'98 Proc, Tucson, AZ, USA, (1998) 1880-1886. 
[21] T. Stumpf, J. Tits, C. Walther, E. Wieland, T. Fanghänel, Uptake of trivalent actinides (curium (III)) by hardened cement paste: a timeresolved laser fluorescence spectroscopy study, J Coll Inter Sci 276 (2004) 118-124.

[22] J. Tits, T. Stumpf, T. Rabung, E. Wieland, T. Fanghänel, Uptake of Cm(III) and Eu(III) by Calcium Silicate Hydrates: A Solution Chemistry and TimeResolved Laser Fluorescence Spectroscopy Study, Environ Sci Technol, 37 (2003) 3568-3573.

[23] E.R. Sylwester, P.G. Allen, P. Zhao, B.E. Viani, Interactions of uranium and neptunium with cementitious materials studied by XAFS. Mat Res Soc Symp Proc 608 (2000) 307-312.

[24] S.L. Matzen, J.M. Beiriger, P.C. Torretto, P. Zhao, B.E. Viani, Uranium(VI) and neptunium(V) transport through fractured, hydrothermally altered concrete, Radiochim Acta, 88 (2000) 657-664.

[25] J. Tits, E. Wieland, M.H. Bradbury, J.P. Dobler, The uptake of Eu(III) and Th(IV) by cement-type minerals in the alkaline disturbed zone of a nuclear waste repository. Proc $6^{\text {th }}$ Int Cong Appl Mineralogy, Göttingen, Germany, 2 (2000) 691-694.

[26] L.P. Moroni, F.P. Glasser, Reactions between cement components and U(VI) oxide Waste Manage, 15 (3) (1995) 243-254.

[27] E. Wieland, I. Bonhoure, T. Fujita, J. Tits, A.M. Scheidegger, Combined wet chemistry and EXAFS studies on the radionuclide immobilisation by cement and calcium silicate hydrates, Geochim Cosmochim Acta Supp 67 (18) (2002) 532

[28] I. Pointeau, C. Landesman, E. Giffaut, P. Reiller, Reproducibility of the uptake of U(VI) onto degraded cement pastes and calcium silicate hydrate phases, Radiochim Acta, 92 (9-11) (2004) 645-650. 
[29] M. Harfouche, E. Wieland, R. Daehn, T. Fujita, J. Tits, D. Kunz, M.

Tsukamoto, EXAFS study of U(VI) uptake by calcium silicate hydrates. J Coll Inter Sci 303 (1) (2006) 195-204.

[30] P. Kumarathasan, G.J. McCarthy, D.J. Hassett, D.F. Pflughoeft-Hassett, Oxyanion substituted ettringites: synthesis and characterization; and their role in immobilization of As, B, Cr, Se and V, Mat Res Soc Symp Proc, 178 (1990) 83-104.

[31] S.C.B. Myneni, S.J. Traina, T.J. Logan, G.A. Waychunas, Sorption and Desorption of Arsenate in Ettringite, Environ Sci Technol 31 (1997) 17611768 .

[32] T. Phenrat, T.F. Marhaba, M. Rachakornkij, A SEM and X-ray study for investigation of solidified/stabilized arsenic-iron hydroxide sludge, J Hazard Mat, 118 (2005) 185-195.

[33] S.A. Stronach, N.L. Walker, D.E. Macphee, F.P. Glasser, Reactions between cement and $\mathrm{As}(\mathrm{III})$ oxide: The system $\mathrm{CaO}-\mathrm{SiO}_{2}-\mathrm{As}_{2} \mathrm{O}_{3}-\mathrm{H}_{2} \mathrm{O}$ at $25^{\circ} \mathrm{C}$, Waste Manage 17 (1997) 9-13.

[34] J. Matsumoto, T. Banba, Sorption behaviour of organic carbon-14 onto cementitious materials, $7^{\text {th }}$ Int Conf Proc Rad Waste Manage Environ Remed, Nagoya, Japan, (1999) CD-ROM.

[35] K. Noshita, T. Nishi, M. Matsuda, T. Izumida, Sorption mechanism of carbon14 by hardened cement paste, Mat Res Soc Symp Proc 412 (1996) 435-42.

[36] T. Banba, J. Matsumoto, S. Muraoka, Adsorption of carbon-14 on Mortar, Mat Res Soc Symp Proc, 353 (1994) 1029-1035. 
[37] P. Brown, J. Bothe Jr., The system $\mathrm{CaO}-\mathrm{Al}_{2} \mathrm{O}_{3}-\mathrm{CaCl}_{2}-\mathrm{H}_{2} \mathrm{O}$ at $23 \pm 2{ }^{\circ} \mathrm{C}$ and the mechanisms of chloride binding in concrete, Cem Concr Res 34 (2004) 15491553.

[38] D. Damidot, U.A. Birnin-Yauri, F.P. Glasser, Thermodynamic investigation of the $\mathrm{CaO}-\mathrm{Al}_{2} \mathrm{O}_{3}-\mathrm{CaCl}_{2}-\mathrm{H}_{2} \mathrm{O}$ system at $25^{\circ} \mathrm{C}$ and the influence of $\mathrm{Na}_{2} \mathrm{O}$, II, Cemento 4 (1994) 243-254.

[39] J.J. Beaudoin, V.S. Ramachandran, R.F. Feldman, Interaction of chloride and C-S-H, Cem Concr Res, 20 (1990) 875-883.

[40] L. Tang, L.O. Nilsson, Chloride binding capacity and binding isotherms of OPC pastes and mortars, Cem Concr Res, 23 (1993) 247-253.

[41] O. Wowra. M.J. Setzer, Sorption of chlorides by hardened cement paste hydrated in jars and by $\mathrm{CSH}$ phases, $13^{\text {th }}$ Int Conf Build Mat, Weimar, 1 (1997) 29-37.

[42] O. Wowra, M.J. Setzer, Sorption of chlorides on hydrated cements and C3S pastes, RILEM Proc, 34 (1997) 146-153.

[43] O. Wowra, M.J. Setzer, About the Interaction of Chloride and Hardened Cement Paste, $3^{\text {rd }}$ Work Bauchemie-Tagung, München, (1997) 3-12.

[44] O. Wowra, M.J. Setzer, About the Interaction of Chloride and Hardened Cement Paste in the Frost resistance of Concrete, RILEM Proc, 34 (1997) 157173.

[45] A. Delagrave, J. Marchand, J.-P. Ollivier, S. Julien, K. Hazrati, Chloride binding capacity of various hydrated cement paste systems. Advn Cem Bas Mat, 6 (1997) 28-35.

[46] V.M. Malhotra, V.S. Ramachandran, R.F. Feldman, P.C. Aitcin, Condensed Silica Plume in Concrete, CRC Press, (1987) 179-184. 
[47] J.J. Beaudoin, V.S. Ramachandran, R.F. Feldman, Interaction of chloride and C-S-H., Cem Concr Res, 20 (6) (1990) 875-883.

[48] P. Yu, R.J. Kirkpatrick, ${ }^{35} \mathrm{Cl}$ NMR relaxation study of cement hydrate suspensions, Cem Conc Res 31 (10) (2001) 1479-1485.

[49] F.P. Glasser, Immobilization of Radwaste in Cement Based Matrices. DoE/RW/89.133, Aberdeen University, Scotland, 1989

[50] M. Toyohara, M. Kaneko, H. Ueda, N. Mitsutsuka, H. Fujihara, T. Murase, N. Saito, Iodine sorption onto mixed solid alumina cement and calcium compounds. J Nucl Sci Tech 37 (11) (2000) 970-978.

[51] M. Toyohara, M. Kaneko, H. Ueda, N. Mitsutsuka, H. Fujihara, N. Saito, T. Murase, Contribution to understanding iodine sorption mechanism onto mixed solid alumina cement and calcium compounds, J Nucl Sci Tech 39 (9) (2002) 950-956.

[52] F.P. Glasser, Chemistry of Cement-Solidified Waste Forms, in Chemistry and Microstructure of Solidified Waste Forms Ed. Spence R.D., Lewis Publishers, Boca Raton, USA, 1993 1-40.

[53] I. Moulin, J. Rosea, W. Stone, J.-Y. Bottero, F. Mosnier, C. Haelmel, Lead, zinc and chromium (III) and (VI) speciation in hydrated cement phases, in: G.R. Woolley, J.J.J.M., Goumans, P.J. Wainwright (Eds.), Waste Materials in Construction, Elsevier, (2000) 269-280.

[54] I. Moulin, W.E.E. Stone, J. Sanz, J.-Y. Bottero, F. Mosnier, C. Haehnel, Lead and zinc retention during hydration of tri-calcium silicate: A study by sorption isotherms and ${ }^{29} \mathrm{Si}$ NMR spectroscopy, Langmuir 15 (1999) 2829-2835.

[55] J. Rose, I. Moulin, J.-L. Hazemann, A. Masion, P.M. Bertsch, J.-Y. Bottero, F. Mosnier, C. Haehnel, X-ray absorption spectroscopy study of immobilization 
processes for heavy metals in calcium silicate hydrates: 1. Case of Lead, Langmuir 16 (2000) 9900-9906.

[56] D.C. Johnson, N.J. Coleman, J. Lane, C.D. Hills, A.B. Poole, A preliminary investigation of the removal of heavy metal species from aqueous media using crushed concrete fines, in: G.R. Woolley, J.J.J.M., Goumans, P.J. Wainwright (Eds.), Waste Materials in Construction, Elsevier, (2000) 1044-1049.

[57] N.J. Coleman, W.E. Lee, I.J. Slipper, Interactions of aqueous $\mathrm{Cu}^{2+}, \mathrm{Zn}^{2+}$ and $\mathrm{Pb}^{2+}$ ions with crushed concrete fines, J Hazard Mat B121 (1-3), 2005, 203213.

[58] N.L. Thomas, D.A. Jameson, D.D. Double, The effect of lead nitrate on the early hydration of Portland cement, Cem Concr Res 11 (1981) 143-153.

[59] F.K. Cartledge, L.G. Butler, D. Chalasani, H.C. Eaton, F.P. Frey, E. Herrera, M.E. Tittlebaum, S.L. Yang, Immobilization mechanisms in solidification/stabilization of cadmium and lead salts using Portland cement fixing agents, Environ Sci Technol 24 (1990) 867-873.

[60] D.L. Cocke J.D. Ortego, H. McWhinney, K. Lee, S. Shukla, A model for lead retardation of cement setting, Cem Concr Res 19 (1) (1989) 156-159.

[61] D.L. Cocke, The binding chemistry and leaching mechanisms of hazardous substances in cementitious solidification/stabilization systems, J Hazard Mat 24 (1990) 231-253.

[62] D.L. Cocke, H.G. McWhinney, G. Hylton, D.C. Dufner, B. Horrell, J.D. Ortego, An XPS and EDS investigation of Portland cement doped with lead(2+) and chromium(3+) cations. Hazard Waste Hazard Mat 6 (3) (1989) 251-257. 
[63] M. Yousuf, A. Mollah, R.K. Vempati, T-C. Lin, D.L. Cocke, The interfacial chemistry of solidification/stabilization of metals in cement and pozzolanic material systems. Waste Manage 15 (2) (1995) 137-148.

[64] S. Asavapisit, G. Fowler, C.R. Cheeseman, Solution chemistry during cement hydration in the presence of metal hydroxide wastes, Cem. Concr. Res. 27 (8) (1997) 1249-1260.

[65] J.D. Ortego, S. Jackson, G.S. Yu, H. McWhinney, D.L. Cocke, Solidification of hazardous substances - a TGA and FTIR study of portland cement containing metal nitrates. J Environ Sci Health A Environ Sci Eng, A24 (6) (1989) 589-602.

[66] C.H. Mattus, A.J. Mattus, Literature review of the interaction of select inorganic species on the set and properties of cement and methods of abatement through waste pre-treatment, in: Stabilization and Solidification of Hazardous, Radioactive and Mixed Wastes, T.M. Gilliam, C.C. Wiles C.C., (Eds.), ASTM: Philadelphia, USA, 1996, pp. 609-633.

[67] J.I. Bhatty, P.B. West, Stabilization of heavy metals in portland cement matrix: Effects on paste properties, in: Stabilization and Solidification of Hazardous, Radioactive and Mixed Wastes, T.M. Gilliam, C.C. Wiles (Eds.), ASTM, Philadelphia, USA, 1996, Vol. III, 147-162.

[68] I. Baur, C.A. Johnson, Sorption of Selenite and Selenate to Cement Minerals. Environ Sci Technol 37 (2003) 3442-3447

[69] P. Kumarathasan, G.J. McCarthy, D.J. Hassett, D.F. Pflughoeft-Hasset, Oxyanion substituted ettringites: synthesis and characterization; and their potential role in immobilization of arsenic, boron, chromium, selenium and vanadium. Mat Res Soc Symp Proc, 178 (1990) 83-104.

[70] C.D. Palmer, Precipitates in a Cr(VI)-Contaminated Concrete, Environ Sci Technol, 34 (2000) 4185-4192. 
[71] M. Zhang, Incorporation of oxyanionic B, Cr, Mo, and Se into hydrocalumite and ettringite : application to cementitious systems, Ph.D. Thesis, University of Waterloo, Canada, 1995 pp1-172.

[72] J.K. Solem-Tishmack, G.J. McCarthy, B. Docktor, K.E. Eylands, J.S. Thompson, D.J. Hassett, High-calcium coal combustion byproducts: engineering properties, ettringite formation, and potential application in solidification and stabilization of selenium and boron, Cem Concr Res 25 (1995) 658-670.

[73] I. Bonhoure, I. Baur, E. Wieland, C.A. Johnson, A.M. Scheidegger, Uptake of Se(IV/VI) oxyanions by hardened cement paste and cement minerals: An Xray absorption spectroscopy study, Cem Conc Res 36 (1) (2006) 91-98.

[74] W. Lerch, F.W. Ashton, R-H. Bogue, The sulfoaluminates. of calcium, J Nat Bureau Stand, 2 (4) (1929) 715-731.

[75] W. Lerch, The influence of gypsum on the hydration and properties of Portland cement pastes, Res Lab Portland Cem Ass Bull RX012 (1946) 1-41.

[76] L. Nachbaur, Etude de l'influence d'electrolytes sur l'hydratation et la prise du silicate tricalcique, composant principal du ciment Portland. Caracterisation des interactions a l'origine de la prise, Ph.D. Thesis, Université de Bourgogne, Dijon, France (1997) pp. 1-141.

[77] L. Divet, R. Randriambololona, Delayed ettringite formation: the effect of temperature and basicity on the interaction of sulfate and C-S-H phase, Cem Concr Res 28 (3) (1998) 357-363.

[78] F. Séby, M. Potin-Gautier, E. Giffault, O.F.X. Donard, A critical review of thermodynamic data for inorganic tin species, Geochim Cosmochim Acta 65 (2001) 3041-3053. 
[79] I. Bonhoure, E. Wieland, A.M. Scheidegger, M. Ochs, D. Kunz, EXAFS Study of Sn(IV) Immobilization by Hardened Cement Paste and Calcium Silicate Hydrates, Environ Sci Technol 37 (10) (2003) 2184-2191.

[80] D. Bonen, S.L. Sarkar, Environmental attack on concrete, Proc $16^{\text {th }}$ Eng Found Conf, Am Soc Civil Eng New York (1994) 11-23.

[81] A. Polettini, R. Pomi, P. Sirini, Fractional Factorial Design To Investigate the Influence of Heavy Metals and Anions on Acid Neutralization Behavior of Cement-Based Products, Environ Sci Technol 36 (2002) 1584-1591.

[82] I. Moulin, Spéciation du plomb, du cuivre, du zinc, du chrome (III) et (VI) dans les hydrates de ciment, Ph.D. Thesis, Université d'Aix-Marseille III, (1998) pp 1-250

[83] D. Savage, The geochemical behavior of nickel in the repository environment, Mat Res Soc Symp Proc 353 (1995) 1159-1166.

[84] T. Heath, D.J. Ilett, C.J. Tweed, Thermodynamic modeling of the sorption of radioelements onto cementitious materials, Mat Res Soc Symp Proc 412 (1996) 443-449.

[85] E. Wieland, L.R. Van Loon, Cementitious Near-Field Sorption Data Base for Performance Assessment of an ILW Repository in Opalinus Clay, PSI Bericht 03-06 14 (2003) 1-74.

[86] M. Vespa, R Daehn, D Grolimund, E. Wieland, A.M. Scheidegger, Co Speciation in Hardened Cement Paste: A Macro- and Micro-Spectroscopic Investigation, Environ Sci Tech 41 (6) (2007) 1902-1908.

[87] L.E. Copeland, E. Bodor, T.N. Chang, C.H. Weise, Reactions of tobermorite gel with aluminates, ferrites, and sulfates. J PCA Res Dev Lab, 9 (1) (1967) $61-74$ 
[88] C.S. Poon, A.I. Clark, C.J. Peters, R. Perry, Mechanisms of metal fixation and leaching by cement based fixation processes, Waste Manage Res 3 (1985) 127-142.

[89] R. Hietanen, E.-L. Kämärainen, M. Aluusua, Sorption of Caesium, Strontium, Iodine, Nickel and Carbon in Concrete, Nuclear Waste Commission of Finnish Power Companies, Report YJT 84-04, Helsinki, Finland, (1984) pp.1-25

[90] M. Ochs, D. Hager, S. Helfer, B. Lothenbach, Solubility of radionuclides in fresh and leached cementitious systems at 22 and $50^{\circ}$ C, Mat Res Soc Symp Proc 506 (1998) 773-780.

[91] N. Pilkington, N. Stone, The solubility and sorption of nickel and niobium under high pH conditions, UK Nirex Ltd Report NSS/R186 (1990)

[92] A.M. Scheidegger, E. Wieland, A. Scheinost, R. Dähn, P. Spieler, Spectroscopic evidence for the formation of layered Ni-Al double hydroxides in cement. Environ Sci Technol 34 (2000) 4545-4548.

[93] C.A. Johnson, F. Glasser, Hydrotalcite-like minerals $\left(\mathrm{M}_{2} \mathrm{Al}(\mathrm{OH})_{6}\left(\mathrm{CO}_{3}\right) 0.5 \mathrm{H}_{2} \mathrm{O}\right.$, where $\left.\mathrm{M}=\mathrm{Mg}, \mathrm{Zn}, \mathrm{Co}, \mathrm{Ni}\right)$ in the environment: Synthesis, characterization, and thermodynamic stability, Clays Clay Min 51 (1) (2003) 1-8.

[94] C. Ludwig, F. Ziegler, C.A. Johnson, Heavy metal binding mechanisms in cement-based waste materials, Stud Environ Sci (Waste Mat Const) 71 (1997) 459-468.

[95] M. Vespa, R Daehn, E. Wieland, D Grolimund, A.M. Scheidegger, The influence of hydration time on the Ni uptake by cement, J Phys 56D (2006) d599-d607. 
[96] F. Ziegler, R. Giere, C.A. Johnson, Sorption Mechanisms of Zinc to Calcium Silicate Hydrate: Sorption and Microscopic Investigations, Environ Sci Technol 35 (2001) 4556-4561.

[97] F. Ziegler, R.E.M. Scheidegger, C.A. Johnson, R. Daehn, E. Wieland, Sorption Mechanisms of Zinc to Calcium Silicate Hydrate: X-ray Absorption Fine Structure (XAFS) Investigation, Environ Sci Technol 35 (2001) 15501555.

[98] G. Arliguie, J. Grandet, Effect of the composition of portland cement on its hydration in the presence of zinc, Cem Concr Res 20 (1990) 517-524.

[99] M. Gawlicki, D.J. Czamarska, Effect of zinc on the hydration of portland cement, Thermal Anal 38 (1992) 2157-2161.

[100] M. Yousuf, A. Mollah, J.R. Parga, D.L. Cocke, An infrared spectroscopic examination of cement-based solidification/stabilization systems - Portland types V and IP with zinc, J Environ. Sci. Health, A27 (6) (1992) 1503-1519

[101] H. Uchikawa, S. Hanehara, H. Hirao, Influence of structural and humidity changes at the inner part of hardened cement paste on autogenous shrinkage, Am Conc Inst, SP 2 (1997) 949-964.

[102] I. Pointeau, B. Piriou, M. Fedoroff, M.-G. Barthes, N. Marmier, F.J. Fromage, Sorption mechanisms of $\mathrm{Eu}^{3}+$ on $\mathrm{CSH}$ phases of hydrated cements, J Coll Inter Sci 236 (2001) 252-259.

[103] M. Schlegel, I. Pointeau, N. Coreau, P. Reiller, Mechanism of Europium Retention by Calcium Silicate Hydrates: An EXAFS Study, Environ Sci Technol 38 (2004) 4423-4431.

[104] M. Atkins, F.P. Glasser, Application of Portland cement-based materials to radioactive waste immobilization, Waste Manage 12 (1992) 105-131 
[105] J. Bensted, S.P. Varma, Ettringite and its derivatives, Cem Technol 2 (1971) 73-76. 